\title{
The Impact of Pandemic Covid-19 Catastrophes on the Survival of Construction Industry in Penang, Malaysia
}

Rekha Muniandy, Md Azree Othuman Mydin

To Link this Article: http://dx.doi.org/10.6007/IJARBSS/v12-i1/10995

DOI:10.6007/IJARBSS/v12-i1/10995

Received: 07 November 2021, Revised: 11 December 2021, Accepted: 24 December 2021

Published Online: 04 January 2022

In-Text Citation: (Muniandy \& Mydin, 2022)

To Cite this Article: Muniandy, R., \& Mydin, M. A. O. (2022). The Impact of Pandemic Covid-19 Catastrophes on the Survival of Construction Industry in Penang, Malaysia. International Journal of Academic Research in Business and Social Sciences, 12(1), 242-252.

\section{Copyright: (c) 2022 The Author(s)}

Published by Human Resource Management Academic Research Society (www.hrmars.com)

This article is published under the Creative Commons Attribution (CC BY 4.0) license. Anyone may reproduce, distribute, translate and create derivative works of this article (for both commercial and non0-commercial purposes), subject to full attribution to the original publication and authors. The full terms of this license may be seen at: http://creativecommons.org/licences/by/4.0/legalcode

Vol. 12, No. 1, 2022, Pg. $242-252$

Full Terms \& Conditions of access and use can be found at http://hrmars.com/index.php/pages/detail/publication-ethics 


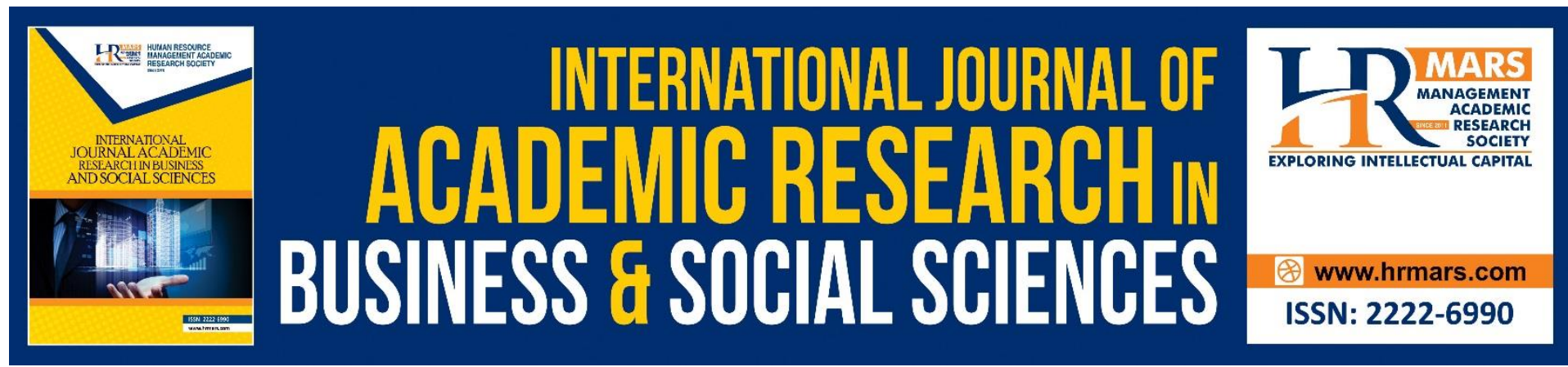

\title{
The Impact of Pandemic Covid-19 Catastrophes on the Survival of Construction Industry in Penang, Malaysia
}

\author{
Rekha Muniandy, Md Azree Othuman Mydin \\ School of Housing, Building and Planning, Universiti Sains Malaysia, 11800, Penang, Malaysia \\ Corresponding Author Email: azree@usm.my
}

\begin{abstract}
Coronavirus (Covid-19) is a disease which outbreaks as pandemic in worldwide. Many countries were affected badly in many situations in terms of economic and business. This pandemic Covid-19 leads to lockdown and restricted movement of people. There were many businesses across different type of sectors were shut down completely which was impacted severely in many countries. One of the sectors is construction industry which faced many crises in terms of development of projects. Therefore, this research is mainly to propose the impact of pandemic Covid-19 catastrophes on the survival of construction industry in Penang. This present study aims to scrutinize the impact of pandemic Covid-19 catastrophes on the survival of construction industry in Penang. This study was carried out two methods for data collection which were questionnaire survey and structured interview. This questionnaire used in this study was structured and unstructured. The research results made clear that the most prominent impacts of Covid-19 are work progress slow down and postpone ongoing projects. The study helps the project stakeholders to be aware of sudden outbreak sequences and steel oneself against difficult challenges during the development project strategy planning stage.

Keywords: Construction Industry, Covid-19, Lockdown, Consultant, Contractor
\end{abstract}

\section{Introduction}

Coronavirus is known as Covid-19 which is a disease that spreading drastically in worldwide in the end of 2019 and till now. This pandemic was originated from Wuhan city in China (Gao \& Yu, 2020). This COVID - 19 is a serious virus where suddenly spread all over the countries. This virus gives huge impact manipulation to the public health and requires immediate internal action. This leads to weak health system to the public health. Due to this pandemic Covid-19, all countries have been in lockdown for several weeks until to get back to new norm (Wang et al., 2020). This lockdown is implemented for movement restrictions of public and avoid spreading virus to one another. Government advised public to stay at home and avoid crowd in public places. In Malaysia, similar as other countries also implemented the protection measure that announced by Malaysia government. Movement restrictions are implemented since 18 March 2020 in nationwide. The government has prerequisite this movement control order with strict standard operation procedure (SOP). Moreover, many sectors are advised to prevent operating and services and fully stop working. Companies must 
implement this social tight measure to avoid spreading virus among workers. Many alternative kinds of sectors are affected severely and face many difficulties in their business and suffered economic losses to country.

As a matter of fact, construction sector is also one of the sectors that affected badly, and construction works are fully shut down. All the workers and engineers are required to stop the progress of construction work at site. This pandemic creates an unforeseen situation to the construction industry. Therefore, government imposed a very tight SOP to the construction industry. This SOP is applicable for all contractors, developers, and foreign workers to keep the construction site safe and hygiene (Singhal, 2020).

In Malaysia, where the Covid-19 is not worst as other countries like USA, UK, Russia, Spain, China and India also implemented a tight safety measure to the public which announced by the Malaysia government (Yuan et al., 2020). All the tourism and hospitality were fully shut down to avoid spreading virus in Malaysia. All the international people who stay in Malaysia had sent them back to their homeland. The government has imposed the restriction as MCO which started since 18 March 2020 and RMCO restriction till now in the year 2021. The construction industry in Malaysia has disrupted severely. It results the industry input is shrunk to $14.9 \%$ in 2020 as all the development activities contained tight measures. The development industry remains sluggish within the year 2020 because the industry has dropped to $44.9 \%$ and weaken the general economy. Although Malaysia government announced to resume working in construction site during CMCO in April 2020, many construction sites altogether states must take ample time to restart the postponed projects. Over 5000 sites were inspected, and 295 sites weren't start their operation due to not implementing the safety measures at sites and 12 sites were stopped working (Brown \& Claeys, 2020).

There are several studies have researched to scrutinize the impact of Covid-19 to construction industry. Construction industry sector was affected severely in worldwide due to the lockdown. All the operating and services in construction industry were shut down which announced by the government. The impact of Covid-19 highlighted the effects on construction projects. Firstly, many construction projects were postponed due to lockdown and the work shifted to Work-From-Home (WFH) to operate the business and services. Most of the professional engineers were worked from home especially office-based construction. A few numbers of employees worked at construction site and engineers monitored them through the surveillance cameras. This method is to reduce the crowd and implemented the safety measures to prevent spread virus at construction sites. Besides that, technology played a major role like artificial intelligence to monitor the work progress at site. This method provides a safety and efficiency at construction site. It increased the project completion in short time under budget and margin profit (Venkitachalam, 2020). Moreover, the climate change has improved because less emission of global greenhouse gas (GHG) during the lockdown. This pandemic also affected on the progress of construction works. Most of the construction projects were stopped due to disruption of supply chain for the projects. Moreover, the suppliers were not ready to re-establish in short term although there was risk in suppliers like imported materials. Health and safety risk assessment was considered in this construction industry because people working in enclosed area is higher risk than the people at outside area. This circumstance was considered to all the employees at construction site to implement the tight safety measures when working at construction site (Ayittey et al., 2020). Furthermore, contractors adjusted their contracts by negotiating about the potential price increased and delayed project. They also checked with their subcontractors and 
suppliers to see any possible solution to solve the disruption of supply chain which delayed the construction projects. Contractors considered an escalation clause in their contracts if there was any increased price and contracts which includes a force majeure that accepts the delays and solution for upcoming projects. Some of the Engineering and Construction companies were impacted badly in funding and risk bankruptcy. Going forward, these companies faced new dispensation which changed the marketplace and infrastructure investment by several "national governments" to begin their recovery. On the other, hand, other companies faced resource limitations. A survey was conducted by Ivanov (2020), 45 projects were completed during the outbreak but proved losses in productivity by $7 \%$ due to shortage of manpower and implemented the social distancing.

In addition, design information that need to transfer is poor when working remotely was produced loss in productivity by $1 \%$ delivery of materials dropped by $7 \%$ due to lockdown whereas Australia blocked the travel to avoid spreading the virus. Because of these unforeseen circumstances, Indonesia and China countries were remain locked and inaccessible for the exportation of goods to the infrastructure and construction sectors. This would slow down the project delivery, but it seemed a good relation between project parties and give solution to produce smooth transition.

This study is mainly to scrutinize the impact of pandemic Covid-19 catastrophes on the survival of construction industry in Penang. The targeted state in Malaysia is Penang which is known as a development city where developing new construction projects in Penang.

\section{Methodology}

Research Design

The research design is classified into two types which are quantitative research and qualitative research. Quantitative research is defined as a systematic investigation of phenomena by gathering quantifiable data and performing statistical, mathematical, or computational techniques. On the other hand, qualitative research relies on data obtained by the researcher from first-hand observation, interviews, questionnaires, focus groups and participant-observation, recordings made in natural settings, documents, and artifacts. The data are generally non - numerical.

\section{Quantitative Data}

This study adopted first method to collect the data by conducting questionnaire survey through emails due to MCO 3.0 in Malaysia. Before conducting the questionnaire survey, invitation emails were sent to all registered email of construction firms in Penang. There were 52 respondents has participated in answering the questionnaire survey to respond to the assessment level of impact using a five Likert type scale. Survey questions may be structured or unstructured. This questionnaire referred as an example from research (Gamil et al., 2020).

\section{Qualitative Data}

This second method that adopted to collect data by conducting structured interview to a project manager in Penang through telephone conversation and email the structured questions along with official letter due to MCO 3.0 in Malaysia. A structured questions was prepared to identify on the survival strategies based on the owners' perspectives. These structured questions referred as an example from research. 


\section{Data Collection}

For valid research the data is the most important thing. The data were divided into two primary and secondary data forms. Both primary data and secondary data were used in this study.

\section{Primary Data}

Primary data is that the data that collected by the questionnaire and interview from the respondents of the targeted area. The foremost widely used method of conducting a survey is primary data chemical analysis. The distinctive main reason qualitative research focuses on straightforwardly gathering data, rather than on data gathered from the previous data analysis thesis. The strategy that uses for the thesis as a primary data is that the questionnaire and interview. The primary data is questionnaire. The questionnaire is that the most vital instrument for all the methodologies and analyses of quantitative study. The second primary data that used for this thesis is that the interview from the respondent through telephone conversation and email.

\section{Secondary Data}

Secondary data is that the data that collected from the opposite researchers, articles, and journals. Previous findings are recorded and compiled to constantly improve research effectiveness. This research includes gathering statistical information from previous data sources like government resources, Internet, research reports, libraries and any further. Secondary data research helps support the information gathered from primary data and improve things solidify or prove or disprove the previous gathered data. The secondary data that get from the information accessible on Internet. Mensuration by using internet is becoming common place with the increasing capacity of mobile devices and internet. Data on many of those research studies is accessible online, which helps to enhance the accuracy of primary data and demonstrate the importance of information that collected. Secondary data for research also may be distributed with the help of state and non-governmental source coping with information sources. This information is

extremely effective and detailed and may therefore be also used enhance the appropriateness of quantitative research.

\section{Sampling Method}

Data will be collecting by distributing the questionnaire to all the construction firms in Penang. The questionnaires were sent to registered email to all construction firms. The main respondents in this research were related professional engineers because the construction firm is the main contributor to Penang development. This study mainly focuses on the impact of pandemic COVID-19 catastrophe on the survival of construction industry in Penang. Two sections are included in this study. The first section is about the participant's demography for the study. In the second section is focused on the assessment of the impacts of pandemic on construction projects. The responded were ranked in the level of effect using 5 Likert type scale. All the data collected from the respondents were statistically analyzed using Microsoft Excel. This software is simple and accurate to obtain the data. It also presents the data using appropriate diagrams, tables and pie chart. To design the sample size of questionnaire, a simple random sampling is used to be an equal probability of being chosen. This study was targeted to 70 respondents for the questionnaires. 


\section{Questionnaire}

In this research, the type of research data that will be used in this research would be the primary data through the survey questionnaires. The survey questionnaire would be distributed through the e-mail. There were 70 questionnaires were distributed to all related engineers in construction firms in Penang through e-mail. First mailing would be an invitation to know the purpose of conducting this questionnaire to the construction firms. The objective of the questionnaire is to collect the data related to the impacts of pandemic on construction projects. A sample of the questionnaire will be presented in the Appendix section.

\section{Results and Discussion}

This section presents the findings of the survey. It will discuss the finding according to the methodology conducted in this study which are questionnaires and structured interview. The data that is collected from questionnaires will be presented by using an appropriate table and diagram. On the other hand, the structured interview data will be presented using the structured questions that answered by the respondent.

\section{Types of Organization}

Figure 1 shows the type of organization. The figure shows that most of the respondents come from clients with $28.8 \%$ which holds the highest percentage among the contractors, consultants, and other parties. The least respondents are contractors with $21.2 \%$. On the other hand, the consultants and other parties holds $26.9 \%$ and $23.1 \%$ respectively.

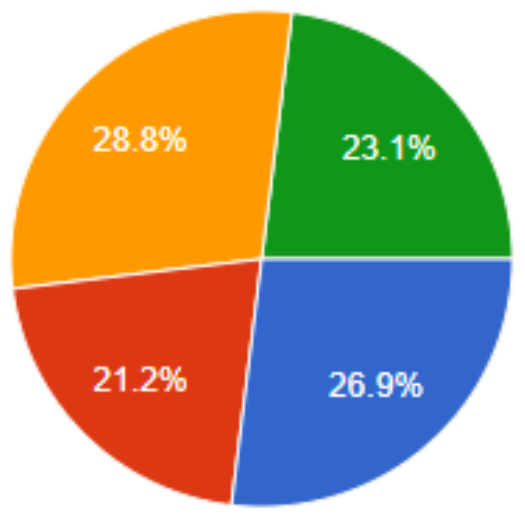

Consultant

Contractor

Client

Other parties

Figure 1. Type of organization

\section{Category of Organization}

Figure 2 shows the category of organization. This categorized as government, private and other category. The highest respondents from private which is $73.1 \%$ whereas respondents from government is $23.1 \%$. The least respondent from other category holds $3.8 \%$ among the government and private sectors. 


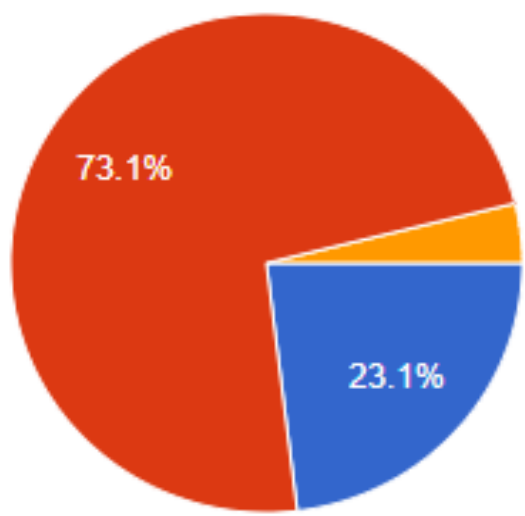

Government

Private

Other category

Figure 2. Category of organization

\section{Role of a Participant in the Organization}

Figure 3 shows the role of a participant in the organization. There are six type of roles that responded by the respondents. The highest percentage of respondents is from other roles with 34.6\%. Respondents from site engineer and architect/ designer holds the same percentage with $17.3 \%$. On the other hand, project manager percentage is $15.4 \%$ which is higher than project engineer with $13.5 \%$. At least percentage holds by company director with $1.9 \%$.

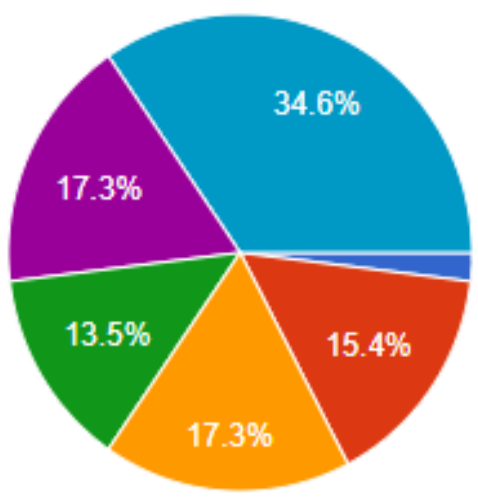

Company Director

Project Manager

Architect/ designer

Project engineer

Site Engineer

Other roles

Figure 3. Role of a participant in the organization

\section{Highest Level of Education}

Figure 4 shows the highest level of education. This education is categorized as diploma, degree, master and PhD. The highest percentage of respondents with degree graduate is $48.1 \%$ and the least respondents with $\mathrm{PhD}$ graduate is $7.7 \%$. The master graduate holds $23.1 \%$ which is higher than diploma graduate with $21.2 \%$. 


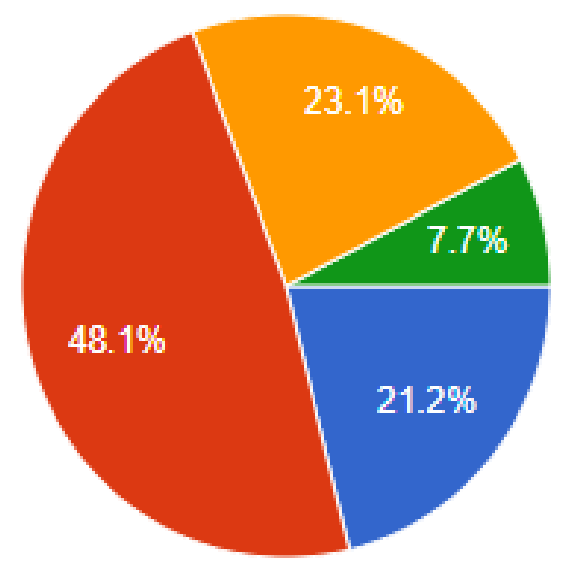

Figure 4. Highest level of education

\section{Years of Experience}

Figure 5 shows the years of experience. The highest percentage of respondents from 0-10 years with $51.9 \%$. Respondents from $11-20$ years holds $25 \%$ which is higher than $21-30$ years with $23.1 \%$. At last, there is no respondents from above 30 years of experience.

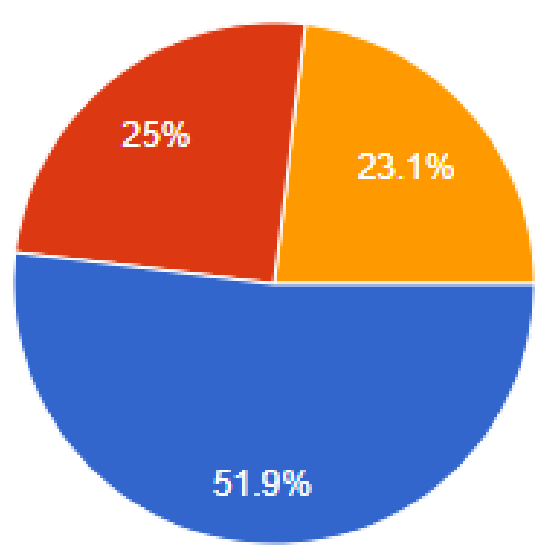

Figure 5. Years of experience

\section{Assessment of Impacts of Pandemic on Construction Projects}

This section will explain on the assessment of impacts of pandemic on construction projects in Penang where the data was collected from the questionnaires that responded by the 52 respondents. There are eight types of impacts of Covid-19 on the construction industry survival in Penang. These data were presented by using bar graph (Figure 6). This section used a five Likert type scale where it categorized as not impacted, slightly impacted, neutral, very impacted, and extremely impacted. Based on the data, the first impact of Covid-19 is lost jobs. There are 20 responses has counted. There are 5 respondents who neutral, very impacted, and strongly impacted in lose jobs due to lockdown. Only 3 respondents are not 
impacted, and 2 respondents are slightly impacted in lose jobs where they are work from home during lockdown.

Next, work progress is slow down which impacted the construction projects. The highest respondents are 35 among these impacts of Covid-19 on the construction industry. There are 19 respondents are extremely impacted the construction work due to movement restriction and many employers are work from home. 8 respondents are very impacted, and the rest are counted least number of respondents which is 1 respondent is not impacted, 2 respondents are slightly impacted, and 5 respondents are neutral with slow progress of work. The third is shortage of supply. There are 20 responses are counted. There are 7 respondents who are extremely impacted with shortage of supply due to lockdown which implemented in many countries. 5 respondents are neutral with shortage of supply because they might not taking any supplies from overseas. The least is 2 respondents who are extremely impacted whereas 3 respondents are not impacted, and 4 respondents are slightly impacted. This can be concluded that few construction firms in Penang are taking supplies from overseas while others are taking supplies from local.

Besides that, many employees from construction firms are badly impacted in low payment of salary. 19 responses have counted. There are 8 respondents are extremely impacted and 6 respondents are very impacted in low payment of salary because most of the employees are work from home and some are in unpaid leave. The rest are least with 1 respondent is not impacted equal with 1 respondent is slightly impacted and 3 respondents are neutral in low payment of salary because some employers make self-finance for the labours. The major impact of Covid-19 is the restrictions of movement on work. 20 responses have counted. There are 10 respondents who are extremely impacted with restriction of movement on work due to lockdown from $18^{\text {th }}$ March 2020 until $28^{\text {th }}$ April 2020. 6 respondents are very impacted. The least respondent is 1 who is neutral with restriction of movement. There are 3 respondents who are not impacted and 2 respondents who are slightly impacted. These respondents are not badly affected because they are work from home and might be working in office-based construction.

Next, time overrun. There are 14 respondents. The highest respondent is 4 who are neutral with the time overrun because they can complete the project before the lockdown. The least respondent is 1 with not impacted because the person might be not sign up for new projects. There are 3 respondents who are slightly impacted similar as very impacted and extremely impacted because they couldn't be able to complete the ongoing projects before lockdown. It seems like they are committed to big projects, and it overruns the time completion.

Postpone ongoing projects is also impacted in construction industry in Penang. There are 30 respondents. There are 18 respondents who are extremely impacted, and 7 respondents are very impacted because many ongoing projects are postponed due to lockdown and takes ample of time to bounce back to normal. The least respondent is 1 who is not impacted, and the rest are 2 respondents who are slightly impacted similar as neutrally impacted because they might not have any ongoing projects or complete before the lockdown.

At last, impact to commit new projects. There are 19 respondents. The highest is 8 respondents who are extremely impacted, and 6 respondents are very impacted to commit new projects because they need to complete the ongoing projects which was in pending due to lockdown. The least respondent is 1 who is not impacted similar as slightly impacted and 3 respondents are neutrally impacted because they might commit to new projects before the 
lockdown. As a conclusion, there are many impacts of Covid-19 on the construction industry's survival in Penang. Many respondents are extremely impacted with work progress slow down and postpone ongoing projects. These impacts hold the highest number of respondents among the other impacts.

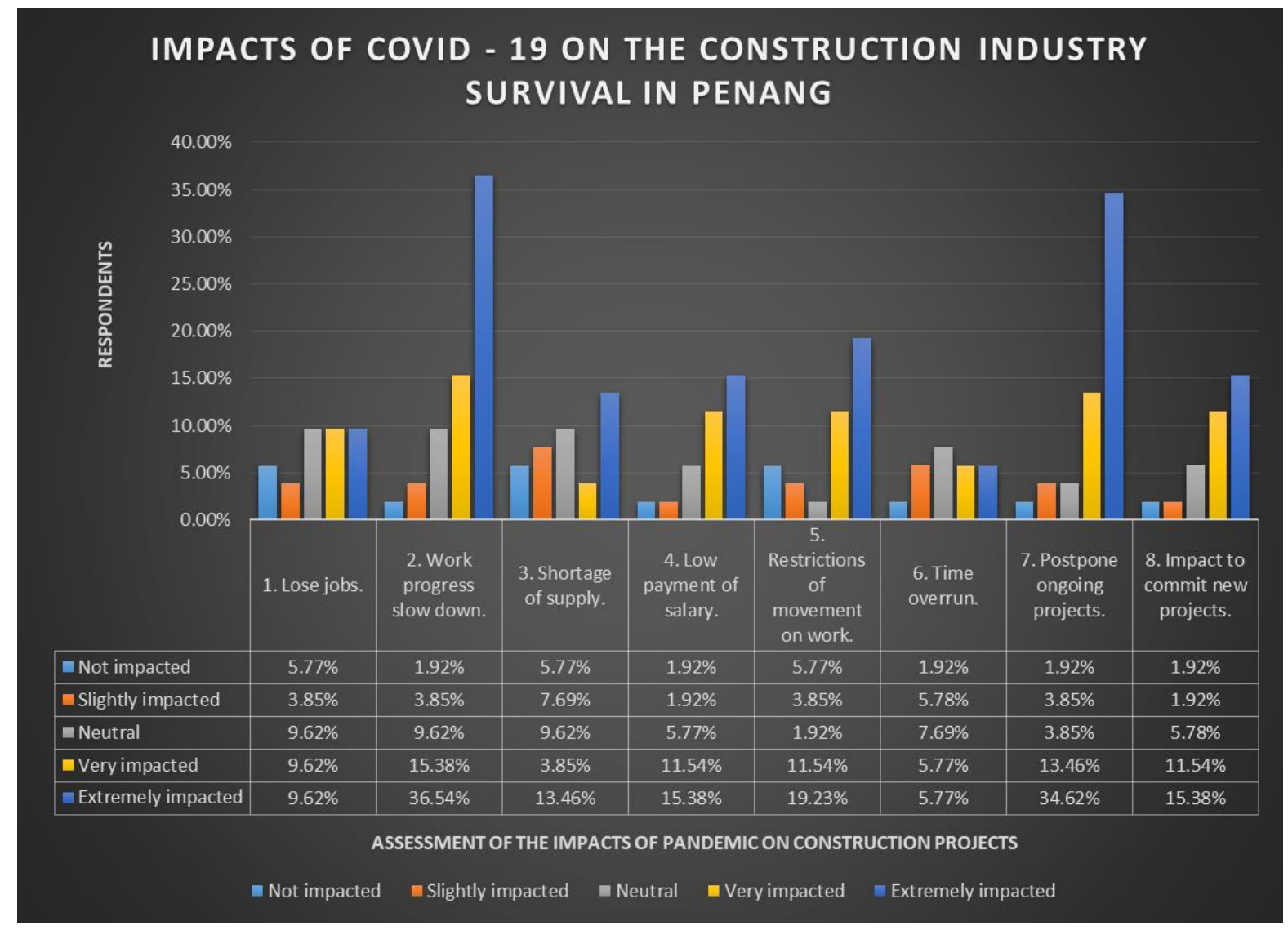

Figure 6. Assessment of impacts of pandemic on construction projects

\section{Conclusion}

This study explored the impacts of pandemic Covid-19 catastrophes on the survival of construction industry in Penang through questionnaire and structured interview. The objective for this research is to scrutinize the impact of Covid-19 on the construction industry's survival in Penang and to identify survival strategies based on the owners' perspectives. This study is mainly focus on primary and secondary data to conduct for data collection. Secondary data is used as baseline throughout this thesis. The primary data collection is done by conducting questionnaire and structured interview. From the questionnaires, it was highlighted the impacts of Covid-19 on the construction industry's survival in Penang. It can be concluded that pandemic Covid-19 has affected in many perspectives and the lockdown contributed difficult obstacles towards the construction projects and development of Penang. At the identical time, it was observed that the amount of SOP compliance among construction players is seen to be better and this new norm should be maintained within the industry to avoid the second wave of Covid-19 in Malaysia. This may help to refine the commitment to address things encountered in future. 


\section{References}

Ayittey, F. K., Ayittey, M. K., Chiwero, N. B., Kamasah, J. S., \& Dzuvor, C. (2020). Economic impacts of Wuhan 2019-nCoV on China and the world. Journal of Medical Virology, 92(5), 473-475

Brown, S., Claeys, L. (2020) Six Steps Construction Companies Can Take to Ride Out the Coronavirus Shock," Associated General Contractors of America.

Gamil, Y., Rahman, I. A., Nagapan, S., \& Alemad, N. (2017). Qualitative approach on investigating failure factors of Yemeni Mega Construction Projects. In MATEC web of conferences, 103, p. 03002. EDP Sciences.

Gao, X., Yu, J. (2020) Public governance mechanism in the prevention and control of the COVID-19: information, decision-making and execution," Journal of Chinese Governance, 0(0) 1-20.

Ivanov, D. (2020). Predicting the impacts of epidemic outbreaks on global supply chains: A simulation-based analysis on the coronavirus outbreak (COVID-19/SARS-CoV-2) case. Transportation Research Part E: Logistics and Transportation Review, 136, 101922

Singhal, T. (2020) A Review of Coronavirus Disease-2019 (COVID-19)," The Indian Journal of Paediatrics

Venkitachalam, J. (2020). Impact of Novel Corona Virus [Covid 19] on the Real Estate Sector of India. Studies in Indian Place Names, 40(73), 211-215

Wang, L., Wang, Y., Ye, D., Liu, Q. (2020) A review of the 2019 Novel Coronavirus (COVID-19) based on current evidence," International Journal of Antimicrobial Agents, 105948.

Yuan, Z., Xiao, Y., Dai, Z., Huang, J., Chen, Y. (2020) A Simple Model to Assess Wuhan Lockdown Effect and Region Efforts during COVID-19 Epidemic in China Mainland," Bulletin of the World Health Organization. 